УДК 347

DOI: 10.31470/2518-7600-2020-9/2-54-87

STATE REGULATION OF ETHNIC RELATIONS IN UKRAINE ON THE BACKGROUND OF THE RUSSIANUKRAINIAN CONFLICT 2014-2020

\title{
ДЕРЖАВНЕ РЕГУЛЮВАННЯ МІЖНАЦІОНАЛЬНИХ ВІДНОСИН В УКРАЇНІ НА ТЛІ РОСІЙСЬКО- УКРАЇНСЬКОГО ПРОТИСТОЯННЯ 2014 - 2020 РР
}

\section{ГОСУДАРСТВЕННОЕ РЕГУЛИРОВАНИЕ МЕЖНАЦИОНАЛЬНЫХ ОТНОШЕНИЙ В УКРАИНЕ НА ФОНЕ РОССИЙСКО-УКРАИНСКОГО КОНФЛИКТА 2014 - 2020 ГГ}

\section{Віталій Коцур,}

кандидат політичних наук, доцент, старший науковий співробітник відділу національних меншин, kotsurv@ukr.net https://orcid.org/0000-00016647-7678

Інститут політичних $\mathrm{i}$ етнонаціональних досліджень ім. І.Ф.Кураса НАН України, вул. Генерала Алмазова, 8. м. Київ, 01011.

\section{Vitalii Kotsur,} Ph.D. in Political Sciences, Assoc. Prof., Senior Research Scientist of the Department of National Minorities kotsurv@ukr.net https://orcid.org/0000-00016647-7678

I. F. Kuras Institute of Political and Ethno-National Research of the National Academy of Sciences of Ukraine 8, General Almazova St., Kyiv, Ukraine, 01011

\section{ABSTRACT}

In the face of geopolitical, socio-economic challenges of the 21 century features of state regulation of interethnic relations in 
Ukraine during the undeclared Russian-Ukrainian war are revealed.

In the article, the annexation of Crimea, the intensification of the «hybrid war» of the Russian Federation against Ukraine is seen as determining foreign policy factors in the politicization of national minorities.

The author notes that the urgent problem since the beginning of the annexation of Crimea was the definition of the status of the Crimean Tatars as «indigenous people».

It is determined that the Russian Federation relied on the Russian national minority in Ukraine to destabilize the situation and launch disintegration processes in order to gain control over part or all of the territory of our state.

It is proved that the legal nihilism of the Russian Federation and the weak resistance of the world community encouraged the aggressor to seize new territories. At the same time, only the Armed Forces of Ukraine were a real counterweight to the invader. At the same time, in 2016, work began on resuming the activities of the Hungarian-Ukrainian, Romanian-Ukrainian and GermanUkrainian commissions, and outlined a number of measures to strengthen national unity and consolidate Ukrainian society.

It was determined that ethno-political, linguistic and educational issues were usually raised in Ukrainian society either during elections in order to mobilize the electorate, or in connection with the intensification of disintegration processes. In the conditions of the Russian-Ukrainian military confrontation, these issues were of security importance and were aimed at preserving the Ukrainian state, the values its civilizational choice - integration into the European community.

Keywords: national minorities, Ukraine, the Russian Federation, interstate relations, «hybrid war», «Russian world».

Постановка проблеми. Політичні зміни, які принесла Революція Гідності, безумовно стали позитивним кроком у формуванні демократично-правової держави з європейськими 
цінностями. Анексія Криму та російська агресія на сході України певною мірою уможливлювалася відсутністю оновленої законодавчої бази в галузі етнонаціональних відносин в Україні, яка б відповідала реаліям часу. Відсутність концепції державної етнонаціональної політики, несвоєчасне i нераціональне оновлення законодавчої бази в сфері національних меншин - усе це полегшувало формування мережі проросійських організацій, які упродовж десятиліть сіяли розбрат в українському суспільстві. Нерішучість влади належним чином реагувати на провокації і незаконні дії з боку сусідніх держав чи їх діаспори в Україні, лише посилювали нестабільність та створювали передумови для сепаратизму в окремих регіонах. Саме тому особливо актуальною впродовж 2014-2018 рр. була модернізація національного законодавства в сфері національної безпеки та нацменшин, як основи стабільності та інтеграції українського суспільства.

Аналіз останніх досліджень публікацій. Етнополітичні процеси в Україні, зокрема, суспільно-політична діяльність національних меншин, неодноразово була предметом дослідження I. Рафальського, М.Панчука, О. Майбороди, В. Войналовича, О. Калакури, В. Котигоренка, О. Рафальського, В. Наулка, О. Ляшенка, Н. Макаренко, Л. Ковач, В. Коцура, Н. Кочан, Ю. Ніколайця, О. Позняк, М. Рябчука та ін. Питання «русского мира», «гібридної війни» розкриті у працях Л. Якубової, С. Магди, В. Горбуліна, А. Котенка, А. Бартоша тощо.

Метою огляду с розкриття особливостей державного регулювання міжнаціональних відносин в Україні в умовах неоголошеної російсько-української

війни, зовнішньополітичного впливу Російської Федерації на етнополітичну ситуацію в країні, що є одним з інструментів «гібридної» політики північного сусіда.

Виклад основного матеріалу. Російська агресія - це серйозні виклики усій світовій спільноті, насамперед Європі, а досвід минулого переконливо доводить, що боротьба за мир має бути активізована, адже політика «умиротворення 
агресора» породжує нові протиправні дії і подальшу ескалацію напруги. Незважаючи на інтеграційний потенціал України, який був у 2014 р., через невдалі дії окремих українських політиків, нерішучість та низку інших обставин не вдалося сформувати потужну законодавчу основу для прискорення націєтворення. У зв'язку з цим залишається актуальним питанням формування на законодавчому рівні правового механізму інтеграції в Україні, шляхом не лише гарантування мовно-культурного розвитку національним меншинам, але й забезпечення політичного, економічного та соціального поступу України в цілому. Розв'язання цих питань сприятиме зміцненню національної безпеки та стабільності всередині країни.

В умовах війни Україні досить складно прийняти низку законодавчих актів для захисту прав національних меншин, насамперед кримських татар після окупації Криму (Газізова, 2016: 144). Водночас прийняття низки важливих законів, які регулюють процеси у сфері національних меншин, мало б стати своєрідним підгрунтям для національної безпеки України та формування інтеграційних процесів всередині країни. Найбільш нагальними законодавчими актами, які мала прийняти держава - це Концепція державної етнонаціональної політики, модернізація Закону України «Про національні меншини України», формування нової мовної нормативноправової бази та закону про «корінні народи».

Актуальною проблемою від початку анексії Криму стало визначення статусу жителів півострова, зокрема кримських татар, а також затвердження на законодавчому рівні гарантії захисту їхніх прав, надання статусу «корінного народу» та ін.

Упродовж 2014-2018 рр. розроблялася низка інших законопроектів, спрямованих на відновлення прав кримських татар.

20 березня 2014 р. було зареєстровано Проект Закону України «Про права корінних народів України», згідно з яким передбачалося визначити народи, які підлягають під критерії 
статусу «корінного» та закріпити за ними правові гарантії на повну реалізацію всіх прав людини та основоположних свобод особами, які належать до корінних народів, згідно з нормами міжнародного права (Газізова, 2016: 145). У документі визначалося поняття «корінного народу» - «автохтонна етнічна спільнота, яка компактно проживає та етногенез якої відбувся на території в межах лінії державного кордону, яка становить етнічну меншість у складі населення України і не має власного державного утворення за межами України» (Проект Закону України «Про права корінних народів України»). Автори проекту указували необхідність забезпечення мовнокультурного розвитку корінних народів, гарантування права на самовизначення у межах України, захисту від дискримінації та геноциду (Проект Закону України «Про права корінних народів України»). Але 27 листопада 2014 р. проект було відкликано, ймовірно через необхідність значного доопрацювання. Відзначимо, що в Україні на даний момент не існує відповідного закону, який би на державному рівні реалізовував норми декларації ООН про захист корінних народів (В Україні немає закону...). За ініціативою Президента України П.О. Порошенка в травні 2015 р., було створено робочу Конституційну групу, яка мала розробити проект змін до Конституції України стосовно самовизначення кримських татар (Гладка). Після внесення пропозицій учасниками парламентських слухань на тему «Стратегія реінтеграції в Україну тимчасово окупованої території Автономної Республіки Крим та міста Севастополь: проблемні питання, шляхи, методи та способи» Верховна Рада України 22 вересня 2016 р. затвердила постановою № 4003-а Рекомендації парламентських слухань (Газізова, 2016: 145). У документі вказується на необхідність формування стратегії реінтеграції Кримського півострова. Так, зокрема, у етнополітичній сфері Президенту України було рекомендовано підготувати зміни до Конституції України стосовно визнання кримських татар, караїмів та кримчаків корінними народами України; Верховна 
Рада України мала прийняти закон про деокупацію та реінтеграцію Автономної Республіки Крим та міста Севастополь, а також внести зміни до Закону України «Про засади внутрішньої і зовнішньої політики»; Кабінет Міністрів України мав виконати низку завдань пов'язаних із розробкою законопроектів стосовно реінтеграції півострову, сприяти створенню правозахисних та благодійних організацій на півострові для захисту прав громадян України, представників національних меншин, громадсько-політичних об'єднань, релігійних організацій, а також залучити міжнародних партнерів, дипломатичних представництв для висвітлення проблеми окупації Криму та утисків кримськотатарського населення та ін. (Рекомендації парламентських слухань...). Проте значна частина рекомендацій не була втілена в практичну площину, а закон про «реінтеграцію», який було прийнято на початку 2018 р. більше стосувався окупованих районів Луганської та Донецької областей.

В умовах антитерористичної операції на сході України, парламент прийняв Закон № 1223-VII «Про відновлення прав осіб депортованих за національною ознакою» від 17 квітня 2014 р. (Газізова, 2016: 143), яким встановлювався статус осіб, депортованих за національною ознакою та гарантії зі сторони держави щодо їх соціально-економічного забезпечення та можливості політичної самореалізації в межах законодавства. Фактично вперше за часів незалежності України на законодавчому рівні було затверджено механізм надання статусу особам, депортованим за національною ознакою, соціальної допомоги, компенсації, а також визначено гарантії держави стосовно захисту репатріантів. Згідно з статтею 4 цього Закону депортованою особою визнається особа, яка набула громадянства України і належить до представників різних народностей, зокрема, кримськотатарської, яка була насильно переселена за національною ознакою рішенням органів державної влади колишнього СРСР з місць їхнього проживання, що є територією сучасної України. До цієї 
категорії відносяться і ті особи, які були відправлені на спецпоселення за межі історичної батьківщини, а також ті, кому було заборонено повертатися на постійне місце проживання (Закон України «Про відновлення прав осіб депортованих за національною ознакою»). В умовах викликів XXI століття, зовнішньої агресії проти України прийняття цього закону відбулося із великим запізненням. Ще у 1990-х pр. під час першої суспільно-політичної кризи на Кримському півострові українські законодавці мали б не лише сформувати відповідний закон, а й створити належні умови репатріантам для активної участі у розбудові краю, що слугувало б важливим запобіжником розгортання російського сепаратизму на території Криму в 2014 р. Водночас враховуючи обставини, що склалися після анексії Криму, документ є одним iз основоположних актів визнання кримськотатарського народу та інших раніше депортованих народів як таких, що не лише потребують захисту від держави, а й можуть допомогти їй у деокупації півострова. Звісно для цього необхідно не лише приймати внутрішні закони, які сприятимуть національнокультурному та політичному розвитку нацменшин півострову, a й формувати політичну i військову стратегію захисту територіальної цілісності та деокупації регіону, спираючись на підтримку міжнародних організацій.

Окупація Російською Федерацією Кримського півострова супроводжувалася чисельними порушеннями прав людини, зокрема, за етнічною ознакою. Спецслужби Росії, внутрішні органи та місцеві колаборанти здійснювали напади, обшуки та арешти місцевих активістів з проукраїнською позицією, серед яких найбільше було українців та кримських татар. Зважаючи на це, керівництво країни, міжнародні організації декларували недопустимість дій окупантів, які порушують низку міжнародних договорів. Так, 15 грудня 2014 р. оприлюднена 8 доповідь Управління Верховного комісара ООН з прав людини про становище в галузі прав людини в Україні, в якій указувалося на недопустимість переслідування кримських 
татар, обмеження свободи слова, необхідність дотримання українського законодавства на півострові та об'єктивного розслідування вбивств і зникнення кримських активістів на півострові (Мазука, Аналітична записка). У резолюції ОБСС «Очевидні, грубі та невиправлені порушення РФ зобов'язань у рамках ОБСС та міжнародних норм» від 8.07.2015 р. було засуджено дії Росії стосовно посягання на територіальну цілісність України (Задорожній, 2015: 195).

Після анексії півострова російське керівництво публічно гарантувало захист прав усіх національностей у Криму, але всі ці заяви політичної еліти Кремля не варті були паперу, на якому написані. Водночас, спостерігалися масові порушення прав людини, зокрема, й національних меншин півострова. Серед усіх національностей, які проживали в Криму, найбільших утисків від окупаційної влади зазнавали кримські татари та українці, які підтримували територіальну цілісність України. Виступи українців, кримських татар та інших народів проти зміни територіального статусу півострова і їх переслідування окупаційною владою зумовили масову міграцію на материкову Україну. У Державній службі України з надзвичайних ситуацій повідомляли, що станом на 2016 р. $з$ півострова переселилося близько 21 тис. кримчан, однак реальна кількість внутрішньо переміщених осіб з Криму може бути набагато вищою (The situation of...). Водночас Меджліс кримськотатарського народу окупаційна влада внесла до списку екстремістських організацій, а його діяльність на півострові була заборонена. За таких обставин, кримськотатарська діаспора в Туреччині та Світовий Конгрес кримських татар, координуючи свої дії 3 українським керівництвом, мало більшу змогу впливати на перебіг подій на півострові, ніж члени Меджлісу (Şahin Fethi Kurtiy...). Окрім того, діаспора кримськотатарського народу могла впливати на політичні рішення українських органів влади у сфері політичного, соціального та економічного розвитку їх представників в Україні, а також активізувати міжнародну співпрацю в боротьбі проти російської агресії та порушень прав людини на Кримському півострові. 
Порушення прав людини, зокрема, за національною ознакою на території півострова, змушувало керівництво України та міжнародних організацій формувати механізми правового захисту та реабілітації цих осіб. Зважаючи на те, що кримські татари найбільше постраждали від окупаційної влади, українським парламентом було прийнято постанову «Про Заяву Верховної Ради України щодо гарантії прав кримськотатарського народу в складі Української держави» від 20 березня 2014 р., згідно з якою гарантовано реалізацію невід'ємного права на самовизначення кримських татар (Газізова, 2016: 144). Документом передбачалося формування нової законодавчої бази, спрямованої на захист прав кримськотатарського народу, залучаючи до цього процесу представників Меджлісу. Постановою також засуджувалися будь-які обмеження політичних прав і свобод осіб за етнічною ознакою в АР Крим після анексії (Постанова Верховної Ради України «Про Заяву Верховної Ради України щодо гарантії ... ). Цією постановою Верховна Рада України фактично визнавала кримських татар як корінний народ, а також заявила свою підтримку Декларації ООН про права корінних народів. Однак цей акт не мав жодного впливу на подальші дії Росії на території півострова (Задорожній, 2015: 205). У червні 2015 р. у парламенті було зареєстровано Проект постанови «Про заяву Верховної Ради України щодо збереження в Україні самобутності і культурної спадщини кримських караїмів (кара) i кримчаків», однак iii не було прийнято (Корінні народи України...).

3 анексією Кримського півострова, одним із головних завдань української влади стало соціальне і правове забезпечення представників кримськотатарського населення, яке вимушено переїхало на материкову Україну. Водночас актуалізувалося питання статусу кримськотатарського народу, враховуючи ситуацію, що склалася на півострові після лютогоберезня 2014 р. Саме тому прийняття відповідного документа мало важливе стратегічне i політичне значення для 
національної безпеки України, особливо коли в інформаційній війні Росії проти України, Москва використовує міфи стосовно «російськості» півострова. Лідери кримськотатарського народу Мустафа Джемілєв та Рефат Чубаров вважають, що майбутнє їхнього народу напряму залежить від надання кримськотатарському народу статус корінного і формування в Криму національно-територіальної автономії в складі України (Аулін). Після анексії Криму, надання статусу «корінного народу» кримським татарам відкривало шлях для залучення міжнародних правах інститутів для захисту інтересів одвічного народу півострова у зв'язку з його масовими арештами. Ю. Тищенко зазначала, що питання статусу «корінного народу» в Україні упродовж незалежності було досить дискурсивним. А дослідниця Н. Бліцер вважає, що за десятиліття Української держави татари так і не спромоглися довести свій статус «корінного народу» для збереження та розвитку власної ідентичності (Навіщо Україні закон про корінні народи?). Отримання цього статусу кримськими татарами прискорювало б процес їхнього самовизначення в межах України.

Ще одним кроком на шляху визнання кримськотатарського народу як «корінного» став Указ Президента України П.О. Порошенка № 841/2014 «Положення про Уповноваженого Президента України у справах кримськотатарського народу» від 3 листопада 2014 р. (Газізова, 2016: 144). У документі зазначається, що Уповноважений забезпечує здійснення Президентом України повноважень у сфері реалізації заходів щодо дотримання конституційних прав кримськотатарського народу «як корінного народу України» (Указ Президента України № 841/2014 ...). Уповноважений виконував низку функцій пов'язаних 3 моніторингом дотримання прав кримськотатарського народу, брав участь у формуванні законопроектів з питань захисту та збереження етнічної, культурної, мовної та релігійної самобутності, а також у розробці пропозицій стосовно захисту територіальної цілісності, інформування громадськості та ін. (Указ Президента 
України № 841/2014 ...). Попри визнання кримських татар як корінного населення, на законодавчому рівні не існувало відповідного закону про корінні народи, що певною мірою лише поглиблювало правові колізії з цього питання. Саме тому представники кримськотатарського народу в українському парламенті працювали над розробленням і реалізацією проекту закону, який, по-перше, формував би критерії для отримання статусу «корінного народу», не допускаючи поширення автономістських та сепаратистських тенденцій, а по-друге визначив би статус кримськотатарського народу на території України.

У листопаді 2015 р. Верховна Рада України прийняла постанову № 792-VIII «Про визнання геноциду кримськотатарського народу». Документом не лише визнавалася депортація кримських татар у 1944 р., але й репресії проти представників цього народу, які здійснювала Російська Федерація після анексії півострова (Газізова, 2016: 144). Відповідно до пункту 3 цього документа системний тиск, репресії та переслідування кримських татар на тимчасово окупованій території розглядається як свідома політика етноциду (Постанова № 792-VIII....). У постанові засуджуються злочини минулого, скоєні керівництвом Радянського Союзу, а також сучасні як етноцид кримськотатарського народу з боку Російської Федерації - правонаступниці СРСР. Керуючись положеннями Конвенції про запобігання злочину геноциду та покарання за цей злочин, народні депутати заявили про свою підтримку кримськотатарському народу.

Упродовж 2014-2018 рр. посилювалося порушення прав людини на Кримському півострові з боку Російської Федерації. Буденною справою стали репресії та обшуки в представників кримськотатарського народу. Так, у першому півріччі 2018 р. було проведено 56 обшуків (з 66) у будинках кримських татар, які російська сторона пов'язувала 3 розповсюдженням «екстремістських матеріалів». Ці обшуки, за інформацією Кримськотатарського Ресурсного Центру, проводилися iз 
застосуванням фізичної сили та порушенням норм міжнародного законодавства (Корінні народи України: ...).

В умовах російської агресії актуалізувалася в Україні потреба розроблення принципово нових концепцій, законопроектів в галузі національної безпеки та запобігання дезінтеграційним процесам. Прийнятий у 2003 р. Закон України «Про основи національної безпеки України», який зазнавав змін у 2006, 2010, 2013, 2014, 2015 та 2017 роках, покликаний був захищати національні інтереси країни та гарантувати їі національну безпеку. У законі названі ключові загрози, як внутрішні, так і зовнішні, що несуть небезпеку для територіальної цілісності і державного суверенітету країни, а також для громадян України, іноземців та осіб без громадянства, які перебувають в країні. Документ захищає національні меншини, де стаття 6 гарантує вільний розвиток, використання і захист їхніх мов i, водночас забезпечувалося українській мові функціонування в усіх сферах суспільного життя як державної (Закон України «Про основи національної безпеки України»). Зважаючи на російську агресію документ тричі зазнавав змін у 2014, 2015 та 2017 роках. Ці зміни переважно торкалися запобіганню загрозам сепаратизму, поширення дезінформації, як одного із способів ведення «інформаційної війни». У пояснювальній записці до проекту закону зазначалося, що прийняття змін до закону зумовлене незавершеністю державотворчих процесів, актуалізацією етнокультурних проблем, етнокультурного розколу в Україні та намаганням політичних сил інших держав поставити під сумнів територіальну цілісність і державний суверенітет України (Етнополітична безпека України, 2015: 70). Водночас Стратегія національної безпеки України, прийнята в травні 2015 р., в основному концентрувала увагу на захисті від російської агресії (Стратегія національної безпеки України), i не включала положень про міжетнічні конфлікти як загрозу національній безпеці. Цей документ критично оцінювався в «Стратегії національної безпеки України (альтернатива)», де 
відзначалося, що прийнятий Президентом України акт має здебільшого декларативний характер, а окремі питання вже прописані в Конституції України та інших законах. Йшлося і про відсутність адекватних відповідей на конкретні загрози, а фундаментальні свободи громадян України розглядалися як другорядні питання національної безпеки. У цій ситуації, окрім відсічі російської агресії та протидії російському політичному та інформаційному впливу, важливо було не допустити дестабілізації всередині країни на грунті занепаду економіки, падіння рівня життя українців та корупції (Стратегія національної безпеки України, 2016: 10-14.). За таких обставин зростає ймовірність етнополітичної дезінтеграції суспільства, зумовленої як відсутністю адекватного законодавчого підгрунтя та ефективних механізмів захисту прав національних меншин, так і зовнішнім впливом зі сторони інших держав, зокрема, Росії, Угорщини та ін.

Усі ці ймовірні ризики важливо було внести до нової редакції Закону України «Про основи національної безпеки». У змінах до Закону за 2015 р. відмічалося, що серед пріоритетів національної безпеки є етнополітична стабільність, а загрозою - спроба утворення незаконних квазідержавних утворень (Етнополітична безпека України, 2015: 72-73). Автори наукової записки «Етнополітична безпека України: політико-правові механізми протидії етнополітичній дезінтеграції держави», порівнюючи редакції Закону 2014 та 2015 років, відмічали, що модернізація змісту документа потребує доповнення положеннями про загрози конституційному ладу, основні напрямки державної політики у сфері національної безпеки та інформаційного простору, протидію неправдивій інформації і, поширення україномовного контенту по всій території держави (Етнополітична безпека України, 2015: 65-66).

В умовах стрімких суспільно-політичних змін XXI ст. запропоновані редакції Закону 2014, 2015 та 2017 років уже не відповідали викликам часу. Саме тому 21 червня 2018 р. Верховною Радою України було прийнято новий Закон України 
«Про національну безпеку України», який скасував дію трьох попередніх законодавчих актів, об'єднавши документи: «Про основи національної безпеки України», «Про демократичний цивільний контроль над Воєнною організацією і правоохоронними органами держави», «Про організацію оборонного планування». Спікер парламенту А. Парубій зазначив, що прийняття документу стало важливим кроком у боротьбі проти російської агресії та для модернізації сектору безпеки й інтеграції до НАТО (Рада ухвалила закон про нацбезпеку з курсом на СС і НАTO). У статті 3 Закону України «Про національну безпеку України» зазначається, що державна політика в сфері безпеки і оборони спрямована на захист людини і громадянина, суспільства і держави (Закон України «Про національну безпеку України»). Як бачимо, питання захисту основних свобод людини посідало чільне місце в документі. Ця думка проходить червоною ниткою «Стратегії національної безпеки України», де захист основних прав і свобод громадян України розглядається як ключовий аспект національної безпеки (Стратегія національної безпеки України, 2016: 14). Водночас документ має і слабкі місця, які зумовлені особливостями державного управління України. У зв'язку з цим військовий експерт Д. Снєгирьов відзначає, що цей закон спрямований на повне переформатування української армії за стандартами НАТО і $є$ зразковим під кутом зору права країн Заходу. Але зважаючи на українські реалії, а саме: корупційну складову, особливо у ЗСУ, всі нововведення можуть залишитися лише декорацією (Ткачук). Окрім того, всі заходи збереження етнонаціональної злагоди, передбаченні законом, частково нівелюються корупційною складовою, яка посилює деструктивні прояви в суспільстві.

Важливим кроком для збереження міжнаціональної злагоди всередині країни стало прийняття у 2017 р. поправок до Закону України «Про засади внутрішньої і зовнішньої політики». Автори документу в пояснювальній записці зазначали, що ксенофобія, міжетнічна ворожнеча негативно 
впливають на державотворення України (Етнополітична безпека України, 2015: 77). На думку авторів монографії «Етнополітична безпека України...», важливо було б доповнити статтю 3 цього закону положеннями про утвердження міжетнічної злагоди в суспільстві та протидію будь-яким проявам ксенофобії (Етнополітична безпека України, 2015: 66). Втім, серед змін внесених у 2017 р., не було цього пункту (Закон України «Про засади внутрішньої та зовнішньої політики»), що відтісняло проблематику етнонаціональної злагоди i боротьбу проти дискримінації за етнічною, релігійною чи расовою ознакою на другий план.

Відзначимо, що прийняття українським парламентом нових освітніх та мовних законів викликало бурхливу реакцію з боку урядів окремих країн, зокрема, Росії, Угорщини та ін. Втім, на думку лідера «Карпатської Січі» Тараса Деяка сепаратизм на Закарпатті є штучним, а ключовою причиною його $є$ нагнітання ситуації окремими політиками (мова йде як про українських, так і про російських та угорських), відсутність діалогу центральної та місцевої влади 3 українцями і національними меншинами. Окрім того, він переконаний, що угорський сепаратизм неможливий і підтвердженням цього є те, що 10 етнічних угорців, загинули захищаючи Україну (Політичне ток-шоу «Пульс», 2018) російсько-українському збройному протистоянні. Більшість етнічних угорців поважає територіальну цілісність і закони України. Водночас антиукраїнські сили використовують освітній та мовний закон як засіб для дезінтеграції суспільства.

У вересні 2017 р. Верховна рада України прийняла Закон України «Про освіту», який викликав чимало дискусій не лише в політичних колах, експертному середовищі, а й закордоном. Особливу увагу привернула стаття 7 закону, згідно з якою мовою освітнього процесу є державна мова, а корінні народи, національні меншини чи іноземці матимуть усі умови для іï вивчення в Україні (Закон України «Про освіту»). Найактивніше критикували закон політичні діячі Росії та 
Угорщини, деякі політичні кола Румунії і Польщі, проросійські політичні сили в Україні, які вбачали в ньому надмірну українізацію та заборону вивчати в школах рідні мови для нацменшин. Активізувалися дискусії стосовно цього питання на Закарпатті як через заяви Угорщини, так і очільників Закарпатської області. Голова Закарпатської ОДА Г. Москаль зазначив, що новий закон суперечить Європейській хартії регіональних мов або мов меншин, Закону України «Про національні меншини України» та міжнародним угодам. Його заступник, який також є лідером «КМКС» Партія угорців України» Й. Борто зазначав, що закон в цілому прогресивний, крім мовної статті. На його думку, стаття 7 обмежує права національних меншин навчатися рідною мовою (Мовний аспект нового закону про освіту викликав чималі дискусії в Закарпатті). Міністр освіти і науки України Л. Гриневич зазначила, що співвідношення предметів, які викладатимуться українською та рідною мовами після 9 класу становитиме відповідно 60 \% і 40 \% (Гриневич). Тобто, навчання окремих предметів буде проводитися й мовами національних меншин, корінних народів. Зокрема, у частині 1 статті 7 зазначається, що їм надаватиметься можливість поряд з українською вивчати рідну мову, відповідно створюючи окремі класи (групи) для навчання (Закон України «Про освіту»).

Посилився науковий і громадський дискурс після скасування мовного закону «Колісніченка-Ківалова» 2012 р. та прийняття Закону України «Про забезпечення функціонування української мови як державної» 4 жовтня 2018 р. Відзначимо, що 4 жовтня 2018 р. розглядалося кілька законопроектів, які регулювали б мовну сферу в Україні. Зокрема, відповідний проект № 5556 «Про мови» було названо декларативним, через відсутність прописаних в ньому механізмів врегулювання мовної ситуації (Депутати підтримали у першому читані громадський законопроект про мову (5670-д)). Народні депутати в першому читані підтримали законопроект № 5670д, який викликав нові дискусії. На думку окремих експертів, 
які підтримували попередній мовний курс, цей документ порушував права нацменшин, які компактно проживають в окремих регіонах України. Звісно, в умовах передвиборчої кампанії заклики стосовно порушення прав нацменшин та окремого статусу російської мови знову ставали предметом нових спекуляцій деяких політичних сил, а отже варто було очікувати і дестабілізації ситуації в Україні шляхом штучного розпалювання міжнаціональної ворожнечі. Водночас цей документ підтверджував, що українська мова $є$ єдиною державною мовою України, яка не обмежує використання мов національних меншин та корінних народів (Проект Закону України «Про забезпечення функціонування української мови як державної»). Хоча в дусі «гібридної війни» в соціальних мережах з'являлися пости про те, що в повсякденному житті заборонятиметься російська чи будь-яка інша мова $з$ метою насильницької українізації всіх сфер суспільного життя. Згідно 3 Конституцією України державна мова поширюється на всі сфери суспільного життя і в цьому ніякого порушення мовних прав національних меншин немає. Водночас, відповідно до частини 2 статті 26 «клієнт має право обслуговуватися будьякою іншою мовою на власну вимогу, а отже це спростовує доводи окремих експертів» (Проект Закону України «Про забезпечення функціонування української мови як державної»). Закон лише передбачає захист української мови як державної i не обмежує використання мов національних меншин у побуті та сфері надання послуг. Цей документ передбачає створення Інституту Уповноваженого із захисту державної мови (Рада підтримала законопроект про державну мову).

В умовах «гібридної війни» політичне протистояння не оминуло церкву з їі багатонаціональним вірянами. Зокрема, одне із бандитських військових формувань на Донбасі носить назву «Російська православна армія», що указує на безпосередній зв'язок терористів з РПЦ та іï структурним підрозділом в Україні - УПЦ (МП). Упродовж російськоукраїнського військового протистояння УПЦ (МП) демонструє 
принципове неприйняття процесів українського національного державотворення. Така політика проявилася у прямій зраді інтересам України. Вірячи в безкарність за колабораціонізм, Кримська і Сімферопольська єпархії систематично відправляють «гуманітарні вантажі» до «новоросії», при цьому підкреслюючи, що «гуманітарна допомога» надається не українцям чи українським громадянам, а для «новоросії» (Кримська єпархія УПЦ; Духовний лідер русинів закликає Росію активно освоювати Закарпаття; Російські терористи на службі в Московського патріархату; Тимчук, 2016; Корректировал «арту»...; Соглашения РПЦ; Договор «О сотрудничестве...; Епископат РПЦ; Деятели Русской православной церкви). Безпосередню координацію та забезпечення антиукраїнської діяльності УПЦ (МП) здійснює найвище державне керівництво Росії, про що відкрито заявив прес-секретар президента РФ Пєсков: «Безусловно, мы считаем недопустимыми какие-либо действия, которые нарушали бы интересы Русской Православной Церкви на Украине» (В Кремле продолжают называть...).

Таким чином, діяльність УПЦ (МП) характеризується постійним використанням релігійних чинників у сучасній антиукраїнській політиці, що вимагає невідкладного реагування та розробки відповідного інструментарію протидії.

Важливою проблемою сьогодення, яка потребує послідовного вирішення у сфері міжетнічних відносин, $є$ забезпечення економічних та соціокультурних запитів населення у зоні конфлікту.

Мова йде, зокрема, про національно-культурні товариства греків у Донецькій області в районі лінії розмежування 3 окупованими територіями. За даними федерації грецьких національних товариств в Україні у 21 області налічується 95 грецьких національно-культурних товариств, зокрема, в зоні ATO -20 .

Ці товариства мають різний статус. Так, обласних лише одне, 34 - мають статус міських, 8 - районних, 38 - сільських (селищних) і одне регіональне. 
3 урахуванням уроків історії, 22 вересня 2016 року, Верховна рада України прийняла Постанову № 4003а «Про рекомендації парламентських слухань на тему: «Стратегії реінтеграції в Україну тимчасово окупованої території Автономної Республіки Крим та міста Севастополь: проблемні питання, шляхи, методи та спроби». На парламентських слуханнях рекомендовано Президенту України підготувати зміни до Конституції і законів України та внести їх на розгляд парламенту щодо створення Кримськотатарської Автономної Республіки (Закірова). Водночас Президент ініціював указ про розробку десятирічної програми вкорінення та зміцнення державного статусу української мови (Порошенко найближчим часом...). Усе це слід розглядати як складники реінтеграції окупованих територій в Україну (Коцур, 2018: 6-15).

Як відомо, в 1995 р. Верховна Рада України прийняла Закон України «Про Автономну Республіку Крим» (Закон України «Про Автономну Республіку Крим»). Водночас ця територіальна автономія створювалася, з одного боку, під впливом російських іредентичних рухів, підживлюваних російськими спецслужбами, а з іншого - при індиферентному ставленні політичного керівництва до проблеми корінних народів Криму i, водночас, побоювання «сепаратизму кримських татар», які не сприймалися кримською проросійською більшістю. Страх «сепаратизму кримських татар» розвіявся після подій 2014 р. - анексії Росією українського Криму (Коцур, 2018: 6-15).

Тож 22 вересня 2016 р. Верховна Рада України 233 голосами народних депутатів прийняла постанову № 4003а «Про рекомендації парламентських слухань на тему: «Стратегія реінтеграції в Україну тимчасово окупованої території Автономної Республіки Крим та міста Севастополь: проблеми, питання, шляхи, методи та спроби». Парламентарі запропонували внести законодавчі зміни щодо позбавлення Севастополя спеціального статусу, а також визнання кримських татар, караїмів і кримчаків корінними народами України 3 
відповідними змінами в ст. 11 Основного закону (Коцур, 2018: 6-15).

18 травня 2016 року під час вечора-реквієму пам'яті жертв геноциду кримськотатарського народу Президент України Петро Порошенко зазначав: «Ми, хоча із запізненням, усвідомили необхідність створення в Криму національної автономії кримських татар $з$ повним гарантуванням рівних прав і громадянських свобод етнічним українцям, росіянам, іншим етносам півострова» (Закірова).

В умовах російсько-українського протистояння 2016 р. розпочалася робота по відновленню діяльності угорськоукраїнської, румунсько-української і німецько-української комісій та було визначено низку заходів щодо зміцнення національної єдності та консолідації українського суспільства(Наказ 01.02.2017 № 70...; Щодо стратегії державної етнонаціональної політики»; Проект Закону про Концепцію...).

В умовах сучасних геополітичних викликів Україні, на думку автора, слід спрямовувати національну самосвідомість меншин у русло розбудови демократії та зміцнення національної безпеки держави. Громадянська і економічна інтеграція національних меншин засобами «народної дипломатії» сприятиме посиленню позицій України в СС, що важливо в нових європейських реаліях, коли Російська Федерація активізувала антиукраїнську роботу в таких країнах як Греція, Угорщина, Словаччина, Болгарія та ін.

Отже, етнополітичне, мовне, освітне питання зазвичай в українському суспільстві піднімалося або під час виборів, 3 метою мобілізації електорату, або у зв'язку із посиленням дезінтеграційних чинників. Водночас, зважаючи на відсутність адекватних механізмів захисту мови як інтеграційного чинника української нації, прийняття відповідних заходів є цілком логічним кроком для державотворення України, а гучні заяви політиків і погрози сепаратизмом через мовне питання штучно нагніталися для маніпуляції суспільною свідомістю та задля мобілізації електорального ресурсу під час виборів. 
Враховуючи сучасні загрози і виклики, варто було б не ослаблювати роботу у Верховній Раді щодо розробки законопроектів про державну мову i мови національних меншин України, освіту нацменшин та зробити їх предметом обговорення широкої громадськості. Потребує систематичного моніторингу політичне, соціокультурне життя нацменшинна Закарпатті, півдні та України сході 3 метою розроблення дорожньої карти по включенню цих регіонів у суспільнополітичні заходи по зміцненню етнополітичної стабільності; на часі багатовимірні наукові розвідки по корекції реформи децентралізації з урахуванням етнонаціонального чинника 3 метою досягнення стабільності і подальшого успішного поступу демократичних перетворень. Залишається актуальними під кутом зору нейтралізації впливу російської пропаганди на український інформаційний простір розвиток телебачення i радіомовлення національних меншин та домінування там державницьких цінностей і демократичних стандартів.

При підготовці проектів державного бюджету важливо передбачати видатки на соціокультурний розвиток нацменшин, запобігання сепаратизму i припинення антиукраїнського мовлення країни-агресора - Російської Федерації в Луганській, Донецькій та Запорізькій областях.

Місцеві державні адміністрації України зобов'язати відновити моніторинг динаміки складу населення за етнічнимпоказником; проведення постійного моніторингу конфліктних ситуацій та політизації етноконфесійних відносин.

На часі державна підтримка проектів наукових установ та університетів у кібер-просторі, спрямованих на поширення знань про історію, культуру, традиції національних меншин і поваги до етнічного різноманіття. Провідною тематикою 3МI, на наш погляд, має бути консолідація національних меншин щодо збереження української держави, цінностей демократичного суспільства. Водночас багатонаціональний український соціум має об’єднатися в умовах повсякденних 
проявів «гібридної війни» $з$ боку Російської Федерації, яка спрямована насамперед на розкол українського суспільства за національною ознакою з метою загальмувати Свропейський поступ Української держави.

\section{ДЖЕРЕЛА ТА ЛІТЕРАТУРА}

1. Аулін О. Закон про статус кримськотатарського народу i де окупацію Криму. URL: https://cutt.ly/ba1LFOZ

2. В Кремле продолжают называть УПЦ «Русской Православной Церковью на Украине». URL: https://cutt.ly/7a1LVn0

3. В Україні немає закону, який реалізовує норми ООН про захист прав корінних народів. URL: https://cutt.ly/Ia1L23r

4. Газізова О. Кримськотатарський рух у просторі державної етнополітики. Актуальне українознавство. 2016. № 4(61). С. $143-145$.

5. Гладка T.I. Кримськотатарське питання в контексті державної етнонаціональної політики України. URL: https://cutt.ly/La1ZwlT

6. Гриневич Л. Мовна стаття закону «Про освіту» не шкодить нацменшинам. URL: https:/life.pravda.com.ua/ columns/2017/10/23/227072/

7. Депутати підтримали у першому читані громадський законопроект про мову (5670-д). URL: https:/cutt.ly/La1ZoZP

8. Деятели Русской православной церкви. URL: http://www.patriarchia.ru/db/text/53175.html;

9. Договор «О сотрудничестве Министерства образования Российской Федерации и Московской патриархии Русской Православной Церкви». Москва, 2 августа 1999 г.URL:

10. Духовний лідер русинів закликає Росію активно освоювати Закарпаття.URL: https://cutt.ly/Ha1ZOV7

11. Епископат РПЦ // Официальный сайт Московского патриархата. URL:http://www.patriarchia.ru/db/persons/30918//

12. Етнополітична безпека України: політико-правові механізми протидії етнополітичній дезінтеграції держави: 
Наукова записка. Горбатенко В.П. (керівник авт. кол.), Шемшученко Ю.С., Кресіна I.О., Стойко О.М. Київ: Інститут держави і права ім. В. М. Корецького НАН України, 2015. С. 70-77.

13. Задорожній О.В. Анексія Криму - міжнародний злочин. Монографія. Київ, 2015. 576 с.

14. Закірова С. Кримськотатарська автономія у складі України: пошук вирішення проблеми. Центр дослідження соціальних комунікацій НБУВ. URL: https:/cutt.ly/za1ZCZ0

15. Закон України «Про Автономну Республіку Крим». URL: http://zakon3.rada.gov.ua/laws/show/95/95-\%D0\%B2\%D1\%80.

16. Закон України «Про засади внутрішньої та зовнішньої політики». URL: http://zakon.rada.gov.ua/laws/show/2411-17

17. Закон України «Про національну безпеку України». URL: http://zakon.rada.gov.ua/laws/show/2469-19

18. Закон України «Про освіту». URL: http://zakon.rada.gov.ua/laws/show/2145-19.

19. Закон України «Про основи національної безпеки України». URL: http://zakon2.rada.gov.ua/laws/show/964-15

20. Закон України «Про відновлення прав осіб депортованих за національною ознакою». URL: http://zakon.rada.gov.ua/ laws/show/1223-18

21. Корінні народи України: захистити права і зберегти культуру.https://www.radiosvoboda.org/a/29420685.html

22. Корректировал «арту»: священник УПЦ МП сбежал в Россию после службы «ДНР». URL: https:// www.obozrevatel.com/ crime/ 06837-korrektiroval-artusvyaschennik-upts-mp-sbezhal-v-rossiyu-posle-sluzhbyi-dnr.htm

23. Коцур В.В. Етнонаціональні процеси в Україні і політичні виклики XXI сто.: кримські виміри. Вчені записки Таврійського національного університету імені В.I. Вернадського. Серія: Історичні науки. Том 29 (68). № 2, 2018. С. 6-15

24. Кримська єпархія УПЦ (МП відправила для так званої «новоросії» черговий «гуманітарний вантаж». URL: https://cutt.ly/Ca1XtTJ 
25. Мазука Л.І. Щодо дотримання прав кримськотатарського народу в анексованому Криму. Аналітична записка. URL: http://www.niss.gov.ua/articles/1798/

26. Мовний аспект нового закону про освіту викликав чималі дискусії в Закарпатті. URL: https://www.radiosvoboda.org/a/ 28729740.html

27. Навіщо Україні закон про корінні народи? URL: http://www.theinsider.ua/rus/politics/553a02f6897dd/

28. Наказ 01.02.2017 № 70Про Експертну раду Міністерства культури України 3 питань етнополітики. Міністерство культури України. URL: http://zakon3.rada.gov.ua/laws/ show/z0246-17

29. Політичне ток-шоу «Пульс». Випуск 2.10.2018. URL: https:// video-ua.112.ua/ politychne-tok-shou-puls-vypusk-vid02102018-280070.html.

30. Порошенко найближчим часом підпише указ про статус державної мови. URL: https://cutt.ly/ha1Xfw7

31. Постанова № 792-VIII «Про визнання геноциду кримськотатарського народу» від 12 листопада 2015 р. URL: http://zakon.rada.gov.ua/laws/show/792-19

32. Постанова Верховної Ради України «Про Заяву Верховної Ради України щодо гарантії прав кримськотатарського народу у складі Української Держави». URL: http:// zakon.rada.gov.ua/laws/show/1140-18

33. Проект Закону про Концепцію державної етнонаціональної політики України. BPУ. URL:http:// w1.c1.rada.gov.ua/pls/zweb2/webproc4_1?pf3511=47852

34. Проект Закону України «Про забезпечення функціонування української мови як державної». URL: http://w1.c1.rada.gov.ua/pls/zweb2/webproc4_1?pf3511=61994

35. Проект Закону України «Про права корінних народів України». URL: http://w1.c1.rada.gov.ua/ pls/ zweb2/ webproc4_1?pf3511=50327

36. Рада підтримала законопроект про державну мову. URL: https://24tv.ua/rada_pidtrimala_zakonoproekt_pro_ukrayinsku_mo vu_n1042063 
37. Рада ухвалила закон про нацбезпеку з курсом на $\mathrm{CC}$ i HATO. URL: https://www.pravda.com.ua/ news/ 2018/06/21/7184067/

38. Рекомендації парламентських слухань на тему «Стратегія реінтеграції в Україну тимчасово окупованої території Автономної республіки Крим та міста Севастополь: проблемні питання, шляхи, методи та способи». URL: http://zakon.rada.gov.ua/laws/show/1602-19

39. Російські терористи на службі в Московського патріархату. URL: https://cutt.ly/la1Xm5V

40. Соглашения РПЦ. URL:http://libelli.ru/athe_act/ aggreem.htm

41. Стратегія національної безпеки України. URL: http://zakon.rada.gov.ua/laws/show/287/2015

42. Стратегія національної безпеки України. Благодійний фонд «Майдан закордонних справ». Луцьк: МКФ «Християнське життя», 2016. С. 10-14.

43. Тимчук Дмитро. Храми УПЦ МП на Донбасі служили складами зброї для російських військ (04 липня 2016 р.). URL: https://cutt.ly/la1XS3v

44. Ткачук Я. (Не)публічний контроль і стандарти НАТО: що варто знати про новий закон про нацбезпеку. URL: https://cutt.ly/0a1XXSc

45. Указ Президента України № 841/2014 «Положення про Уповноваженого Президента України у справах кримськотатарського народу» від 3 листопада 2014. URL: https://cutt.ly/Ka1X989

46. Щодо стратегії державної етнонаціональної політики». НІСД. URL:http://old.niss.gov.ua/book/StrPryor/6/7.pdf

47. Şahin Fethi Kurtiy A bridge between Ukraine and Turkey: Crimean Tatars diaspora. URL: https://cutt.ly/7a1CwjS

48. The situation of national minorities in Crimea following it's annexation by Russia. URL: https://cutt.ly/ja1Cprk 


\section{REFERENCES}

1. Aulin, O. Zakon pro status krymskotatarskoho narodu $i$ de okupatsiiu Krymu[Law on the status of the Crimean Tatar people and the occupation of Crimea]. Retrieved from: https://cutt.ly/ra1CL59

2. V Kremle prodolzhaiut nazblvat UPTs «Russkoi Pravoslavnoi Tserkoviu na Ukrayne»[The Kremlin continues to call the UOC the «Russian Orthodox Church in Ukraine»]. Retrieved from: http:// www.religion.in.ua/news/ vazhlivo/36527-v-kremle-prodolzhayutnazyvat-upc-russkoj-pravoslavnoj-cerkovyu-na-ukraine.html

3. V Ukraini nemaie zakonu, yakyi realizovuie normy OON pro zakhyst prav korinnykh narodiv [There is no law in Ukraine that implements UN norms on the protection of the rights of indigenous peoples]. Retrieved from: https://cutt.ly/5a1Vpz1

4. Hazizova, O. (2016). Krymskotatarskyi rukh u prostori derzhavnoi etnopolityky [Crimean Tatar movement in the space of state ethnopolitics]. Aktualne ukrainoznavstvo [Current Ukrainian studies]. 4(61).143-145 [in Ukrainian].

5. Hladka, T.I. Krymskotatarske pytannia v konteksti derzhavnoi etnonatsionalnoi polityky Ukrainy [The Crimean Tatar question in the context of the state ethno-national policy of Ukraine]. Retrieved from: http://www.dy.nayka.com.ua/?op=1\&z=799

6. Hrynevych, L. Movna stattia zakonu «Pro osvitu» ne shkodyt natsmenshynam» [The language article of the law «On Education» does not harm national minorities]. Retrieved from: https:/life.pravda.com.ua/columns/2017/10/23/227072/

7. Deputaty pidtrymaly u pershomu chytani hromadskyi zakonoproekt pro movu (5670-d) [Deputies supported in the first reading the public bill on language (5670-d)]. Retrieved from: http://language-policy.info/2018/10/deputaty-pidtrymaly-vpershomu-chytanni-hromadskyj-zakonoproekt-pro-movu-5670-d/

8. Deiately Russkoi pravoslavnoi tserkvy [Figures of the Russian Orthodox Church]. Retrieved from: http://www.patriarchia.ru/db/ text/53175.html. 
9. Dohovor «O sotrudnychestve Mynysterstva obrazovanyia Rossyiskoi Federatsyy y Moskovskoi patryarkhyy Russkoi Pravoslavnoi Tserkvy»h». Moskva, 2 avhusta 1999 h. [Agreement «On Cooperation between the Ministry of Education of the Russian Federation and the Moscow Patriarchate of the Russian Orthodox Church» Moscow, August 2, 1999].

10. Dukhovnyi lider rusyniv zaklykaie Rosiiu aktyvno osvoiuvaty Zakarpattia [The spiritual leader of the Ruthenians calls on Russia to actively explore Transcarpathia]. Retrieved from: http://risu.org.ua/ua/index/all_news/community/religion_and_polic $\mathrm{y} / 56703 /$

11. Epyskopat RPTs // Ofytsyalnui sait Moskovskoho patryarkhata [Episcopate of the ROC // Official site of the Moscow Patriarchate]. Retrieved from: http://www.patriarchia.ru/ db/persons/30918/.

12. Etnopolitychna bezpeka Ukrainy: polityko-pravovi mekhanizmy protydii etnopolitychnii dezintehratsii derzhavy (2015). [Ethnopolitical security of Ukraine: political and legal mechanisms to combat ethnopolitical disintegration of the state]. Naukova zapyska [Scientific note]. Horbatenko V.P. (kerivnyk avt. kol.), Shemshuchenko Yu.S., Kresina I.O., Stoiko O.M. Kyiv: Instytut derzhavy i prava im. V. M. Koretskoho NAN Ukrainy [Institute of State and Law. VM Koretsky NAS of Ukraine] 70-77 [in Ukrainian].

13. Zadorozhnii, O.V. (2015). Aneksiia Krymu - mizhnarodnyi zlochyn [The annexation of Crimea is an international crime]. Monohrafiia [Monograph]. Kyiv. 576 [in Ukrainian].

14. Zakirova, S. Krymskotatarska avtonomiia u skladi Ukrainy: poshuk vyrishennia problemy[Crimean Tatar autonomy within Ukraine: the search for a solution]. Tsentr doslidzhennia sotsialnykh komunikatsii NBUV [NBUV Center for Social Communications Research]. Retrieved from: https://cutt.ly/Ma1BN2s

15. Zakon Ukrainy «Pro Avtonomnu Respubliku Krym» [Law of Ukraine «On the Autonomous Republic of Crimea»]. Retrieved from: http:/ zakon3.rada.gov.ua/ laws/ show/ 95/95$\% \mathrm{D} 0 \% \mathrm{~B} 2 \% \mathrm{D} 1 \% 80$. 
16. Zakon Ukrainy "Pro zasady vnutrishnoi ta zovnishnoi polityky» [Law of Ukraine «On Principles of Domestic and Foreign Policy»]. Retrieved from: http://zakon.rada.gov.ua/laws/show/ 2411-17

17. Zakon Ukrainy "Pro natsionalnu bezpeku Ukrainy» [Law of Ukraine «On National Security of Ukraine»]. Retrieved from: http://zakon.rada.gov.ua/laws/show/2469-19

18. Zakon Ukrainy «Pro osvitu» [Law of Ukraine «On Education»]. Retrieved from: http://zakon.rada.gov.ua/ laws/show/2145-19.

19. Zakon Ukrainy «Pro osnovy natsionalnoi bezpeky Ukrainy» [Law of Ukraine "On Fundamentals of National Security of Ukraine»]. Retrieved from: http://zakon2.rada.gov.ua/ laws/show/964-15

20. Zakon Ukrainy «Pro vidnovlennia prav osib deportovanykh za natsionalnoiu oznakoiu» [Law of Ukraine «On Restoration of the Rights of Persons Deported on National Grounds»]. Retrieved from: http://zakon.rada.gov.ua/laws/show/1223-18

21. Korinni narody Ukrainy: zakhystyty prava i zberehty kulturu [Indigenous peoples of Ukraine: protect rights and preserve culture]. Retrieved from: https://www.radiosvoboda.org/a/29420685.html

22. Korrektyroval «artu»: sviashchennyk UPTs MP sbezhal v Rossyiu posle sluzhbu «DNR» [Corrected the «art»: the priest of the UOC-MP fled to Russia after the service of the «DNR»]. Retrieved from: https://cutt.ly/ca1NCq2

23. Kotsur, V.V. (2018). Etnonatsionalni protsesy v Ukraini $i$ politychni vyklyky XXI sto.: krymski vymiry[Ethno-national processes in Ukraine and political challenges of the XXI century: Crimean dimensions]. Vcheni zapysky Tavriiskoho natsionalnoho universytetu imeni V.I. Vernadskoho [Scientific notes of Tavriya National University named after VI Vernadsky]. Seriia: Istorychni nauky [Series: Historical Sciences]. 29 (68). 2. 6-15 [in Ukrainian].

24. Krymska yeparkhiia UPTs (MP vidpravyla dlia tak zvanoi «novorosii» cherhovyi "humanitarnyi vantazh»[The Crimean Eparchy of the Ukrainian Orthodox Church (MP) sent another 
«humanitarian cargo» for the so-called «new Russia»]. Retrieved from: https://cutt.ly/Ga1MRVH

25. Mazuka, L.I. Shchodo dotrymannia prav krymskotatarskoho narodu $v$ aneksovanomu Krymu [Regarding the observance of the rights of the Crimean Tatar people in the annexed Crimea]. Analitychna zapyska [Analytical note]. Retrieved from: http://www.niss.gov.ua/articles/1798/

26. Movnyi aspekt novoho zakonu pro osvitu vyklykav chymali dyskusii $v$ Zakarpatti [The linguistic aspect of the new law on education has provoked considerable debate in Transcarpathia]. Retrieved from: https:/www.radiosvoboda.org/a/28729740.html

27. Navishcho Ukraini zakon pro korinni narody? [Why Ukraine law on indigenous peoples?]. Retrieved from: http:// www.theinsider.ua/rus/politics/553a02f6897dd/

28. Nakaz 01.02.2017 № 70 Pro Ekspertnu radu Ministerstva kultury Ukrainy z pytan etnopolityky[Order 01.02.2017 № 70 On the Expert Council of the Ministry of Culture of Ukraine on Ethnopolitics]. Ministerstvo kultury Ukrainy [Ministry of Culture of Ukraine]. Retrieved from: http:// zakon3.rada.gov.ua/ laws/show/z0246-17

29. Politychne tok-shou «Puls» (2018). [Political talk show «Pulse»]. Retrieved from: https://video-ua.112.ua/politychne-tokshou-puls-vypusk-vid-02102018-280070.html.

30. Poroshenko naiblyzhchym chasom pidpyshe ukaz pro status derzhavnoi movy [Poroshenko will soon sign a decree on the status of the state language]. URL: https://cutt.ly/ta1M6N5

31. Postanova № 792-VIII «Pro vyznannia henotsydu krymskotatarskoho narodu» vid 12 lystopada 2015 r. [Resolution № 792-VIII «On the recognition of the genocide of the Crimean Tatar people» of November 12, 2015]. Retrieved from: http://zakon.rada.gov.ua/laws/show/792-19

32. Postanova Verkhovnoi Rady Ukrainy «Pro Zaiavu Verkhovnoi Rady Ukrainy shchodo harantii prav krymskotatarskoho narodu u skladi Ukrainskoi Derzhavy» [Resolution of the Verkhovna Rada of Ukraine «On the Statement of the Verkhovna Rada of Ukraine 
on Guaranteeing the Rights of the Crimean Tatar People within the Ukrainian State»]. Retrieved from: http://zakon.rada.gov.ua/ laws/show/1140-18

33. Proekt Zakonu pro Kontseptsiiu derzhavnoi etnonatsionalnoi polityky Ukrainy [Draft Law on the Concept of State EthnoNational Policy of Ukraine]. VRU. Retrieved from: https://cutt.ly/Ra11v0w

34. Proekt Zakonu Ukrainy «Pro zabezpechennia funktsionuvannia ukrainskoi movy yak derzhavnoi»[Draft Law of Ukraine «On Ensuring the Functioning of the Ukrainian Language as the State Language»]. Retrieved from: http:// w1.c1.rada.gov.ua/pls/zweb2/webproc4_1?pf3511=61994

35. Proekt Zakonu Ukrainy "Pro prava korinnykh narodiv Ukrainy» [Draft Law of Ukraine «On the Rights of Indigenous Peoples of Ukraine»]. Retrieved from: http://w1.c1.rada.gov.ua/ pls/zweb2/webproc4_1?pf3511=50327

36. Rada pidtrymala zakonoproekt pro derzhavnu movu [The Council supported the draft law on the state language]. Retrieved from: https:// 24tv.ua/ rada_pidtrimala_zakonoproekt_pro_ ukrayinsku_movu_n1042063

37. Rada ukhvalyla zakon pro natsbezpeku z kursom na YeS $i$ NATO [The Council adopted a law on national security with a focus on the EU and NATO]. Retrieved from: https:// www.pravda.com.ua/news/2018/06/21/7184067/

38. Rekomendatsii parlamentskykh slukhan na temu «Stratehiia reintehratsii $v$ Ukrainu tymchasovo okupovanoi terytorii Avtonomnoi respubliky Krym ta mista Sevastopol: problemni pytannia, shliakhy, metody ta sposoby" [Recommendations of the parliamentary hearings on «Strategy for reintegration into Ukraine of the temporarily occupied territory of the Autonomous Republic of Crimea and the city of Sevastopol: problematic issues, ways, methods and ways»]. Retrieved from: http:// zakon.rada.gov.ua/laws/show/1602-19

39. Rosiiski terorysty na sluzhbi v Moskovskoho patriarkhatu [Russian terrorists in the service of the Moscow Patriarchate]. 
Retrieved from: https://informnapalm.org/ua/rosijski-terorysty-nasluzhbi-v-moskovskogo-patriarhatu/

40. Sohlashenyia RPTs [Agreements of the ROC]. Retrieved from: http://libelli.ru/athe_act/aggreem.htm

41. Stratehiia natsionalnoi bezpeky Ukrainy [National Security Strategy of Ukraine]. Retrieved from: http://zakon.rada.gov.ua/ laws/show/287/2015

42. Stratehiia natsionalnoi bezpeky Ukrainy (2016). [National Security Strategy of Ukraine]. Blahodiinyi fond «Maidan zakordonnykh sprav» [Foreign Affairs Maidan Charitable Foundation]. Lutsk: MKF «Khrystyianske zhyttia» [Lutsk: IFF «Christian Life»]10-14 [in Ukrainian].

43. Tymchuk, D. (2016). Khramy UPTs MP na Donbasi sluzhyly skladamy zbroi dlia rosiiskykh viisk (04 lypnia 2016 r.)[Timchuk Dmitry. The temples of the Ukrainian Orthodox Church in Donbas served as weapons depots for Russian troops]. Retrieved from: https://cutt.ly/ya10PX1

44. Tkachuk, Ya. (Ne)publichnyi kontrol i standarty NATO: shcho varto znaty pro novyi zakon pro natsbezpeku [(Non) public control and NATO standards: what you need to know about the new law on national security]. Retrieved from: https://24tv.ua/ zakon_pro_natsionalnu_bezpeku_ukrayini_2018_vse_pro_zakon_n atsbezpeki_n933297

45. Ukaz Prezydenta Ukrainy № 841/2014 «Polozhennia pro Upovnovazhenoho Prezydenta Ukrainy u spravakh krymskotatarskoho narodu» vid 3 lystopada 2014 [Decree of the President of Ukraine № 841/2014 «Regulations on the Plenipotentiary of the President of Ukraine for the Crimean Tatar people» of November 3]. Retrieved from: https:// www.president.gov.ua/documents/8412014-17960

46. Shchodo stratehii derzhavnoi etnonatsionalnoi polityky»[On the strategy of state ethno-national policy]. NISD [NISS]. Retrieved from: http://old.niss.gov.ua/book/StrPryor/6/7.pdf

47. Şahin Fethi Kurtiy A bridge between Ukraine and Turkey: Crimean Tatars diaspora. Retrieved from: https://cutt.ly/ua106iL 
48. The situation of national minorities in Crimea following it's annexation by Russia. Retrieved from: https://cutt.ly/Za12sOI

\section{АНОТАЦІЯ}

В умовах геополітичних, сочіально-економічних викликів XXI cm. розкрито особливості державного регулювання міжнаціональних відносин в Україні в період неоголошеної російсько-украӥнської війни. У дослідженні анексія Криму, посилення «гібридної війни» Російській Федераџій проти України розглядається як визначальні зовнішньополітичні чинники політизації національних меншин.

Автор проводить думку про те, щзо нагальною проблемою від початку анексї Криму стало визначення статусу кримських татар, як «корінного народу».

Визначено, щуо Російська Федерачія робила ставку на російську наимменшину в Україні для дестабілізаиії ситуаиї та запуску дезінтегращійних прочесів з метою здобути контроль над частиною або усією територією нашої держави.

Доведено, щуо правовий нігілізм РФ і слабкий опір світової спільноти заохочували агресора до захоплень нових територій. Водночас реальною противагою загарбнику були лише Збройні Сили України. Водночас у 2016 р. розпочалася робота 3 відновлення діяльності угорсько-української, румунськоукраӥнської $і$ німецько-украӥнської комісій, а також було окреслено низку заходів щзодо зміцнення національної єдності та консолідації українського суспільства

Визначено, щуо етнополітичне, мовне, освітнє питання зазвичай в украӥнському суспільстві порушувалися або під час виборів з метою мобілізації електорату, або у зв'язку із посиленням дезінтеграційних процесів. В умовах російськоукраӥнського військового протистояння иј питання мали безпекове значення $i$ були спрямовані на збереження Української держави, ичінностей ї̈ ичвілізаційного вибору інтеграиії до європейського співтовариства. 
Ключові слова: національні меншини, Україна, Російська Федерація, міждержавні відносини, «гібридна війна», «русский мир».

\section{АННОТАЦИЯ}

В условиях геополитических, социально-экономических вызовов XXI века раскрыты особенности государственного регулирования межнациональных отношений в Украине в период необъявленной российско-украинской войны. В исследовании аннексия Крыма, усиление «гибридной войны» Российской Федерации против Украины рассматривается как определяющие внешнеполитические факторы политизации национальных меньшинств.

Автор проводит мысль о том, что насущной проблемой с начала аннексии Крыма стало определение статуса крымских татар, как «коренного народа».

Определено, что Российская Федерация делала ставку на российскую нацменьшинство в Украине для дестабилизации ситуации и запуска дезинтеграционных процессов с целью получить контроль над частью или всей территории нашего государства.

Доказано, что правовой нигилизм РФ и слабое сопротивление мирового сообщества поощряли агрессора к захватам новых территорий. В то же время реальным противовесом захватчику были только Вооруженные Силы Украины. В то же время в 2016 началась работа по восстановлению деятельности венгерско-украинской, румынско-украинской и немецко-украинской комиссии, а также были обозначены ряд мер по укреплению национального единства и консолидации украинского общества

Определено, что этнополитическое, языковое, образовательное вопрос обычно в украинском обществе нарушались или во время выборов с целью мобилизации электората, или в связи с усилением дезинтеграционных процессов. В условиях российско-украинского военного 
противостояния эти вопросы должны сфере безопасности значение и были направлены на сохранение Украинского государства, ценностей ее цивилизационного выбора интеграции в европейское сообщество.

Ключевые слова: национальные меньшинства, Украина, Российская Федерация, межгосударственные отношения, «гибридная война», «русский мир». 